\title{
Republika Czarnogóry jako potencjalny cel rosyjskich dzialań wywiadowczych (wprowadzenie do problemu)
}

Czarnogóra, niepodległa od 3 czerwca 2006 r., jest jednym z mniejszych państw Europy. Na obszarze 13812 km² zamieszkuje około 627 tys. osób (dane z 2009 r.) ${ }^{1}$. Atrakcyjność Czarnogóry odkrywaja nie tylko turyści, w tym Polacy, ale także zagraniczni inwestorzy i, jak należy domniemywać, obce służby specjalne. Strona, która osiaga aktualnie istotna pozycję $\mathrm{w}$ realizacji na terytorium Czarnogóry przedsięwzięć biznesowych, jak również szpiegowskich, sa Rosjanie. Ich gospodarczą obecność można próbować przedstawić za pomoca konkretnych danych (np. ilości udziałów w czarnogórskich przedsiębiorstwach, które poddane zostały $\mathrm{w}$ ostatnich latach procesowi przekształceń własnościowych). Równie wymiernymi parametrami nie da się jednak określić skali penetracji Czarnogóry przez rosyjskie służby wywiadowcze. Istotne jest jednak dostrzeżenie, charakterystycznej dla działań Moskwy, podejmowanych w wielu państwach, korelacji inicjatyw ekonomicznych i „specjalnych”. W zasadzie nie ma podstaw do tego, by istnienia powyższej prawidłowości nie zauważać akurat

${ }^{1}$ Dane za: F. Šístek, Černá Hora, Praha 2007; M. Mikołajczak, Czarnogóra, [w:] Vademecum batkanisty. Lata 500-2007, red. I. Czamańska, Z. Pentek, Poznań 2009. 
w państwie czarnogórskim, położonym w ważnej - z punktu widzenia interesów Rosji - części Europy².

Czarnogórsko-rosyjska współpraca polityczna, ekonomiczna, a okresowo również wojskowa, ma tradycje sięgające końca XVIII w. Rosja wspierała w XIX w. czarnogórskie dążenia wolnościowe. Subsydiowała władze Czarnogóry i jej prawosławne duchowieństwo, a także wojsko (na przełomie XIX i XX w.). Współcześnie w Czarnogórze, mimo prozachodniej orientacji politycznej (czy może raczej polityczno-ekonomicznej) większej części społeczeństwa, wciąż darzy się dużą estymą Rosję, rosyjską kulturę wysoka, jak również zwierzchników Rosyjskiej Cerkwi Prawosławnej, a do pewnego stopnia także siły zbrojne państwa rosyjskiego oraz, kojarzonych dzięki mediom, głównych liderów politycznych Federacji Rosyjskiej (prezydent, premier, szef dyplomacji).

Po dojściu do władzy w Czarnogórze Milo Đukanovicia na początku lat 90. XX w. (w latach 1991-1998 premiera, następnie prezydenta, później ponownie kilkakrotnie premiera), a zwłaszcza po przyjęciu przez niego orientacji prozachodniej, Czarnogóra stała się państwem mocno politycznie spolaryzowanym (zwolennicy rozluźniania więzi z Serbia i zbliżenia z Zachodem, skupiający się wokół premiera contra orędownicy ścisłych związków z Serbia, integrujacy się przy ówczesnym prezydencie Momirze Bulatoviciu). Następnie stopniowo dostawała się pod wpływy opcji prozachodnio-niepodległościowej. Jej umacnianie się stało się możliwe

${ }^{2}$ Zob. m.in.: Руска политика на Балкану: зборник радова, ур. Ј. Курјак, Београд 1999; К. Никифоров, Између Кремља и Републике Српске (завршна етапа босанске кризе), Београд 2000; M. Korzeniewska-Wiszniewska, Rosyjskie wptywy polityczne $i$ gospodarcze $w$ Republice Serbii dzisiaj, [w:] Międzycywilizacyjny dialog w świecie stowiańskim w XX i XXI wieku. Historia - religia - kultura - polityka, pod red. I. Stawowy-Kawki, Kraków 2012, s. 365-377. 
jeszcze w warunkach wspólnoty z Serbią (tzw. trzecia Jugosławia w latach 1992-2003; Serbia i Czarnogóra w latach 2003-2006) - wskutek rozbicia partii M. Bulatovicia przez M. Đukanovicia, a następnie $\mathrm{w}$ warunkach prezydentury (1998-2002) i kolejnego premierostwa tego ostatniego (2003$2006)^{3}$. Szczególnie po konflikcie o Kosowo (marzec-czerwiec 1999 r.) $)^{4}$, Czarnogóra, pozostająca już w bardzo słabych więziach z Serbia, obrała, obowiazujący do dziś, kurs na integrację z Zachodem. Przejawia się on we współpracy (także wojskowej) z Niemcami ${ }^{5}$ oraz sympatiach do tego państwa, jak też m.in. do Włoch, Austrii i Wielkiej Brytanii. Wyrażanemu zamiarowi wstapienia do Unii Europejskiej (UE) i NATO towarzyszyło otwarcie Podgoricy na zachodnie, zwłaszcza

${ }^{3}$ O. Sofransky, S.R. Bowers, M.T. Doss Jr., Montenegro: Vassal or Sovereign?, „Liberty University. Faculty Publications and Presentations - Helms School of Government”, 28 I 2009, http://digitalcommons.liberty. edu/cgi/viewcontent.cgi?article=1027\&context=gov_fac_pubs (dostęp 7 XII 2013); W. Szczepański, Pożegnanie z Jugostawiq: Wspólnota Państwowa Serbia i Czarnogóra (2003-2006), [w:] Bałkany Zachodnie między przesztościa a przyszłościa, pod red. P. Chmielewskiego i S.L. Szczesio, Łódź 2013, s. 461475; idem, Główne problemy polityczne jugostowianskiej Republiki Czarnogóry w okresie od kwietnia 1992 r. do marca 1999 r., [w:] Batkany w XX i XXI wieku. Historia - polityka - kultura. Materiaty z konferencji „Poznać Batkany”, Toruń, 29 maja 2009 roku, pod red. H. Stysa i Sz. Sochackiego, Toruń 2009, s. 43-59; idem, Wspólnota programowo pęknięta: Serbia i Czarnogóra - przygotowania do rozwodu?, „Puls Świata” 2005, nr 3 (13), s. 32-35.

${ }^{4}$ Zob.: K. Pawłowski, Kosowo. Konflikt $i$ interwencja, Lublin 2008; A. Makowski, Sojusz Pótnocnoatlantycki wobec konfliktów w bytej Jugostawii, [w:] Euroatlantycka przestrzeń bezpieczeństwa, red. nauk. J. Czaja, Warszawa 2005, s. 165-194. Na temat sytuacji w Kosowie w całym okresie od wojny 1999 r. do jednostronnej proklamacji suwerenności w Prisztinie (17 lutego 2008 r.) zob. A. Malinowski, Od autonomii do niepodlegtości. Ewolucja problemu Kosowa w latach 1974-2008, Choszczno-Gorzów Wlkp. 2010, s. 249-356.

${ }^{5}$ D. Noack, Hilfstruppen, ,German Foreign Policy” (Bonn), 17 III 2010. 
włoskie, niemieckie i austriackie (choć wymienić należałoby także węgierskie i słoweńskie) inwestycje.

W kolejnym okresie przewodzenia przez M. Đukanovicia czarnogórskiemu rządowi (rozpoczętym w lutym 2008 r.) zainicjowany został jednak kurs na gospodarcze zbliżenie z Federacją Rosyjska. U źródeł tego tkwił zapewne w jakiejś mierze fakt, iż czarnogórski premier był już wówczas do pewnego stopnia „spalony” w Europie Zachodniej (zwłaszcza we Włoszech) - w związku z oskarżeniami o niedemokratyczne rządy, tolerowanie mafii, czy wręcz czerpanie profitów z jej działalności (przemyt papierosów, narkotyków, broni, a nawet żywego towaru) ${ }^{6}$. Władze Federacji Rosyjskiej zaś otwarcie, bez tego typu zastrzeżeń, Đukanovicia popieraja.

Mimo iż udział państw zachodnich (a także wspomnianych już w niniejszym kontekście Węgier) w inwestycjach w Czarnogórze pozostaje znaczący ${ }^{7}$, aktywność rosyjska na tym polu do niedawna stale wzrastała. Rosjanie (The Central European Aluminum Company, CEAC, oraz EN+, kontrolowane przez Olega Deripaskę) skupili w swoich rękach na pewien czas większość akcji (około 2/3) czarnogórskich podmiotów strategicznych: kombinatu aluminiowego w Podgoricy (Kombinat aluminjuma Podgorica, KAP) i kopalni boksytów Rudnik w Nikšiciu. Sprzedaż Rosjanom udziałów KAP

${ }^{6}$ M. Lopušina, Milo. Jedna evropska priča, Niš 2005, s. 39-46.

7 „Dan” (Podgorica), 28 VIII 2009, s. 7; „Pobjeda” (Podgorica), 29 VIII 2009, s. 5; „Vijesti” (Podgorica), 6 IX 2013, s. 7.

${ }^{8}$ Pochodząca sprzed kilku lat, niemniej wciąż zachowująca wartość, charakterystyka O. Deripaski, jego różnorodnych biznesów (aluminium, motoryzacja, banki, ubezpieczenia, budownictwo, spółka lotnicza - powiązane w holding Basic Element) oraz posiadanych przezeń związków biznesowo-towarzyskich (m.in. z doradzającymi mu Jamesem Wolfensohnem i Klausem Mangoldem), zob. M. Kuntz, Ein Oligarch und Seine Freunde, „Süddeutsche Zeitung” (München), 9 VIII 2007, s. 20. 
sfinalizowana została 1 grudnia 2005 r. osobiście przez O. Deripaskę i premiera M. Đukanovicia. W radzie dyrektorów KAP oraz Rudnika zasiadło wówczas trzech Rosjan: Wiaczesław Kriłow, Andrej Kuzniecow i Aleksej Kuzniecow9.

Od 2007 r. w wymienionych przedsiębiorstwach narastać zaczęły poważne problemy, mimo iż Rosjanie jakoby zainwestowali w nie aż około 200 mln euro (oszacowanie rosyjskie).

Pierwszą z kwestii, wymagających pilnego rozwiązania, było już wtedy zaopatrzenie KAP w prąd. Problem ten powracał później w odniesieniu do kolejnych podmiotów czarnogórskiej gospodarki, współzarządzanych przez Rosjan. Zdaje się, iż jego najlepszym rozwiązaniem, preferowanym przez samych Czarnogórców, mogło okazać się wybudowanie i oddanie w porę do eksploatacji drugiego bloku elektrowni cieplnej w mieście Pljevlja (Termoelektrana „Pljevlja” u Pljevljima), co byłoby pierwszym od 1982 r., kiedy uruchomiono tę elektrownię, dużym przedsięwzięciem w czarnogórskiej energetyce $^{10}$. Rozumieli to inwestorzy z Rosji. Rosyjska grupa EN+ zamierzała zrealizować przedmiotowy projekt już w $2007 \mathrm{r}$. Została jednak pozbawiona takiej możliwości decyzją czarnogórskiego parlamentu ${ }^{11}$. Niedługo potem rozgorzał też spór o podział stanowisk w radzie nadzorczej KAP. Latem $2013 \mathrm{r}$. czarnogórskie dzienniki zdominowały informacje o zadłużeniu KAP, grożącym nawet zamknięciem kombinatu i zwolnieniami pracowników, zawirowaniach własnościowych wokół

${ }^{9}$ Por.: http://www.kap.me/index1.php?module=1\&menu=8; http://www. ceacgroup.com/; http://www.enplus.ru; http://www.dan.co.me/?nivo=3\&rubrika=Ekonomija\&clanak=257983\&datum=2010-12-02; http://en. wikipedia . org/; wiki/Podgorica_Aluminium_Plant (dostęp 10 XII 2010 - wszystkie cytowane materiały); ,Dan”, 28 VIII 2009, s. 7.

${ }^{10}$ N. Uskoković, Kina protiv Evrope, „Dnevne novine” (Podgorica), 4 IX 2013, s. 2.

${ }^{11}$ Rusi opet u igri, „Dnevne novine”, 4 IX 2013, s. 2. 
przedsiębiorstwa, jak również o nowej fazie czarnogórsko-rosyjskich targów o to, w jaki sposób w radzie nadzorczej tego przedsiębiorstwa powinni być reprezentowani najważniejsi udziałowcy (obok rosyjskich CEAC, EN+ i VTB sa nimi czarnogórski Skarb Państwa i Elektroprivreda Crne Gore, EPCG) i jakiej wysokości mają być dotacje państwa oraz kredyty, uzyskiwane dla KAP w niemieckich bankach, których gwarantem jest Ministerstwo Finansów Czarnogóry ${ }^{12}$. Uwagę poświęcano również, dodatkowo komplikującemu sytuację kombinatu, konfliktowi o uregulowanie jego należności za energię elektryczna, nielegalnie przejętą z międzynarodowego interkonektora energetycznego (udziałowcy rosyjscy uznaja za elementy czarnogórskiej polityki naciskowej względem nich aresztowanie dyrektora finansowego KAP Dimitrija Potrubača, odpowiadającego za pozyskanie nieprzysługującego KAP prądu, a także nie zgadzają się na pokrycie przez rząd czarnogórski powstałych należności za energię elektryczną z pieniędzy, które wcześniej obiecał on Rosjanom) ${ }^{13}$.

Wykorzystując Międzyrządowy Rosyjsko-Czarnogórski Komitet ds. Handlu, minister ds. sytuacji nadzwyczajnych Federacji Rosyjskiej, Władimir Puczkow, naciskał na początku września 2013 r. na rząd Republiki Czarnogóry, jednoznacznie upominając się o prowadzenie przezeń polityki gospodarczej w sposób umożliwiajacy zabezpieczenie interesów rosyjskich

${ }^{12}$ N. Uskoković, Pritisak vlade Rusije zbog KAP-a, „Dnevne novine”, 6 IX 2013, s. 3; D.M., Dug KAP-a prebijaju preko budžeta, „Dan”, 6 IX 2013, s. 5; Ma.-M.-Iv. G., Opet kredit da sad imaju za plate i penzije, „Vijesti”, 6 IX 2013, s. 5; M.M., Još 250 radnika KAP-a može u penziju, ,Vijesti”, 6 IX 2013, s. 5; EPCG prednjači sa neuplatom doprinosa, „Vijesti”, 6 IX 2013, s. 6 (w tekście pokazane są powiązania EPCG z KAP i konsekwencje, jakie ponosi EPCG w związku z zaległościami finansowymi, które posiada w stosunku do niej KAP).

${ }^{13}$ N. Uskoković, Pritisak vlade Rusije..., s. 3. 
w KAP. Było to uzasadniane w dokumencie rosyjskim troską o wspólny interes Czarnogórców i Rosjan oraz o kondycję gospodarczą całej Czarnogóry ${ }^{14}$. Apel rosyjskiego ministra nie cofną oczywiście decyzji o postawieniu kombinatu w stan upadłości (ogłoszono ją w lipcu 2013 r.), niemniej możliwe, iż dopomoże on rosyjskim udziałowcom przedsiębiorstwa, a więc firmom kontrolowanym przez O. Deripaskę, w skutecznym egzekwowaniu należności, jakie - według rosyjskich oszacowań - powinny trafić w ręce CEAC, EN+ oraz VTB w związku z likwidacją KAP (łącznie około $120 \mathrm{mln}$ euro) ${ }^{15}$.

Z poważnym kryzysem borykał się w ostatnich latach nie tylko KAP, ale również Rudnik boksita z Nikšicia, kontrolowany przez Rosjan z CEAC, od którego jeszcze niedawno kopaliny kupować chciał po preferencyjnych cenach kontrahent węgierski - firma Vagon impex Andrása Rasko ${ }^{16}$, interesujący się także (o czym będzie jeszcze mowa poniżej) przejęciem całego nikšickiego przedsiębiorstwa. W latach 2011-2013 w Rudniku boksita często wybuchały strajki ${ }^{17}$. Podobnie jak KAP, kopalnia boksytów z Nikšicia popadła $\mathrm{w}$ tarapaty, m.in. w związku z brakiem dostaw prądu dla tego przedsiębiorstwa, spowodowanym jego długami. Decyzją zarządu zawiesiło ono działalność w pierwszym kwartale 2012 r., mając wówczas nieuregulowane zobowiązania

\section{${ }^{14}$ Ibidem.}

${ }^{15}$ Novo ročište za povjerioce, „Vijesti”, 8 IX 2013, s. 5.

${ }^{16}$ Sv.M., Madari raskidaju ako ne dobiju rudu, „Vijesti”, 6 IX 2013, s. 7; idem, U pondeljak preti raskid, „Vijesti”, 7 IX 2013, s. 6.

${ }^{17}$ B. Brašnjo, Rudari blokiraju izvoz boksita, „Dan”, 23 VIII 2011, s. 1; V. Kadić, Radnici „Boksita” $i$ dalje blokiraju izvoz, http://www.novosti.rs/vesti/planeta.300.html:452118-Radnici-Boksita-i-dalje-blokiraju-izvoz (dostęp 8 XII 2013); http://www.portalanalitika.me/ekonomija/vijesti/124673-radnici-boksita-blokirali-izvoz-rude (dostęp 7 XII 2013); http://www.rtvatlas.tv/vijesti/ekonomija/2069-blokiran-izvoz-rude-iz-boksita.html (dostęp 8 XII 2013). 
wobec pracowników (m.in. 24\% wynagrodzeń należnych załodze za listopad 2011 r., całych wynagrodzeń za grudzień 2011 r. i styczeń 2012 r., a także - co stanowiło przedmiot sporów sądowych - dwóch pensji z miesięcy letnich 2011 r.). $\mathrm{W}$ tak napiętej sytuacji rozważano rządowa pomoc dla kopalni, którą obiecywali jej m.in. przewodniczący Skupsztiny Czarnogóry, Ranko Krivokapić, oraz doradca premiera (okresowo będący także przedstawicielem rządu w zarządzie firmy) - Predrag Stamatović ${ }^{18}$. Jednym z poważniejszych scenariuszy, które rozważano już wówczas, było doprowadzenie do przejęcia kontroli nad kopalnia przez rodzima firmę Neksan z Nikšicia, kierowaną przez Miodraga Dakę Davidovicia - rzutkiego biznesmena, posiadającego dobre relacje ze związkowcami (postulowali niegdyś dokooptowanie go do czarnogórskiej Rady Ministrów). Tenże Davidović od maja 2011 r. odpowiadał, na mocy specjalnego porozumienia biznesowo-technicznego, zawartego 15 marca 2011 r., za organizację produkcji w zakładzie Nikšićka Železara $^{19}$. Nie bez powodów zatem wyobrażano sobie, że scalenie w jego rękach kontroli nad dwoma ważnymi podmiotami gospodarczymi z Nikšicia stanowić mogłoby milowy krok w kierunku uzdrowienia sytuacji wydobywczego sektora gospodarki czarnogórskiej. Brak określonych gwarancji rządowych (szczególnie w kwestii subwencji, z których Neksan zamierzał pokryć koszty dostawy prądu dla kopalni boksytów), długotrwałe zamieszanie z Rosjanami o zaległe należności dla górników ${ }^{20}$, a także inne nierozwiązane, nieco mniej

${ }^{18}$ Nikšić: , „Neksan” hoće u rudnik boksita, 12 III 2012, http://www.novosti.rs/vesti/planeta.300.html:370342-Niksic-Neksan-hoce-u-rudnik-boksita (dostęp 28 I 2015).

${ }^{19}$ Ibidem.

${ }^{20} \mathrm{~W}$ grudniu 2012 r. 70 z 554 pracowników wyprocesowało w końcu około 100 tys. euro zaległości od CEAC, niemniej nierozstrzygnięte 
istotne, problemy, powodowały, że sytuacja Rudnika boksita długo nie znajdowała rozwiązania, zaś M. Davidović ogłaszał już (np. latem 2012 r.) swoją rezygnację ze starań o przejęcie przedsiębiorstwa ${ }^{21}$. Według stanu $\mathrm{z}$ początku września 2013 r., ponad 300 górników, zatrudnionych w tym przedsiębiorstwie (zwolnienia z 2011 r. objęły aż 320 osób ${ }^{22}$ ), nie miało zapłaconych pensji nawet przez kilkanaście miesięcy z rzędu. Inne zobowiązania (dodatki, nagrody jubileuszowe, ekwiwalenty zimowe i przestojowe) nie były regulowane w firmie przez trzy do pięciu lat ${ }^{23}$. W kontekście powyższego, w jednej z odnotowanych przez prase na początku września 2013 r. informacji na temat sytuacji w kopalni, padły znamienne słowa. Oto pracownicy, kontestujący sytuację przedsiębiorstwa i swoja własna, zapytywali, jak możliwe stało się popadnięcie kopalni w wielkie zadłużenie, podczas gdy jej sytuację kontrolowała rzekomo rosyjska CEAC wraz z czarnogórskim rządem, oraz dlaczego de facto kopalniany dług ma CEAC niejako wobec siebie samej i z pracy górników chce go sobie spłacić, choć prawdopodobne jest, że wcześniej określone kwoty po prostu (współ)defraudowała? ${ }^{24}$

pozostały pozwy z żądaniami szacowanymi na około $1,5 \mathrm{mln}$ euro, obejmującymi spłaty wynagrodzeń pozostałych pracowników oraz dodatkowo roszczenia zbiorcze z tytułu różnych ekwiwalentów i nagród gwarantowanych, Boksiti dobili spor protiv CEAK-a, 10 XII 2012, http://www.bankar. me/2012/12/10/boksiti-dobili-spor-protiv-ceak-a/ (dostęp 21 I 2015).

${ }^{21}$ Czarnogóra: Fabryka wyrobów tytoniowych zamiast kopalni, 5 VII 2012, http://balkanistyka.org/czarnogora-fabryka-wyrobow-tytoniowych-zamiast-kopalni/ (dostęp 28 IV 2015); Czarnogóra: Brak porozumienia w sprawie kopalni boksytów, 23 VI 2012, http://balkanistyka.org/czarnogora-brak-porozumienia-w-sprawie-kopalni-boksytow/ (dostęp 29 IV 2015).

${ }^{22}$ B. Brašnjo, op. cit., s. 1.

${ }^{23}$ Sv.M., op. cit., s. 7.

${ }^{24}$ Ra.P., Nezadovoljni rudari odlučni da ne dozvole izvoz boksita ni po koju cenu, ,Pobjeda”, 2 IX 2013, s. 1. 
19 listopada 2013 r. ogłoszona została w sądzie upadłość zakładu Rudnik boksita ${ }^{25}$. Zadłużenie firmy szacowane było wówczas na około $130 \mathrm{mln}$ euro, a rosyjską kompanię CEAC wskazywano publicznie jako ponosząca odpowiedzialność za doprowadzenie do katastrofalnej sytuacji czarnogórskiego przedsiębiorstwa ${ }^{26}$. Dopiero 30 grudnia 2014 r. syndyk masy upadłościowej Rudnika boksita - Zdravko Cićmil - przedłożył warunki umowy o przejęciu produkcji dwóm inwestorom (czarnogórski Neksan oraz węgierski Vagon impex), pozostałym w grze o kontrolę nad kopalniąa ${ }^{27}$. W styczniu 2015 r. rozstrzygnięty został przetarg na przejęcie Rudnika boksita za 9,5 mln euro (dwie wcześniejsze wyceny opiewały odpowiednio na $14 \mathrm{mln}$ i 10,7 mln euro). Przedsiębiorstwo znalazło się ostatecznie pod kontrolą Neksanu, który w okresie od ogłoszenia upadłości kopalni do grudnia 2014 r./stycznia 2015 r. - na podstawie specjalnej umowy - organizował ograniczone wydobycie boksytów ze złóż Zagrad i Štitovo. Powierzenie zakładu czarnogórskiej firmie Neksan M. Davidovicia, z którą o przejęcie kopalni konkurowali w 2014 r. zrazu inwestorzy polski (Onico) i, wspomniany już wcześniej, węgierski (Vagon impex), a następnie już tylko drugi z wymienionych podmiotów, oznacza zdecydowanie się przez Czarnogórców na konsolidację biznesu górniczego w rodzimych rękach. Rozwiązanie powyższe, kwestionowane przez przegranego inwestora, pochodzącego $\mathrm{z}$ Węgier ${ }^{28}$, przyjęte zostało

${ }^{25} \mathrm{http}: / / w w w . r t v a t l a s . t v / v i j e s t i / e k o n o m i j a / 2069-b l o k i r a n-i z v o z-r u d e-i z-$ -boksita.html (dostęp 8 XII 2013).

${ }^{26}$ V. Dimitrevska, Montenegro's Neksan set for partnership with Rudnici Boksita - report, http://wire.seenews.com/news/montenegro-s-neksan-set-for-partnership-with-rudnici-boksita-report-459408 (dostęp 21 I 2015).

${ }^{27}$ S. Mandić, Mađari ili Neksan? Ko će preuzeti Boksite, znaće se za 10 dana: stečajni upraunik poslao predloge, ,Vijesti”, 5 I 2015, s. 1.

${ }^{28}$ Jako byłemu kontrahentowi Rudnika boksita oraz pretendentowi do jego przejęcia związkowcy, kierowani przez Iliję Đilasa, a także 
z satysfakcją i ulga przez większość zainteresowanych tą sprawą Czarnogórców ${ }^{29}$. Stanowisko to najjaśniej wyraził chyba inżynier z kopalni z Nikšicia - Ilija Miljanić, stwierdzając, że po doświadczeniach z rosyjską CEAC O. Deripaski, który doprowadził to jedno z ważniejszych czarnogórskich przedsiębiorstw do upadłości i zadłużeń, sięgających 130 mln euro, Rudnik boksita nie potrzebuje już pozostawać pod zarządem jakiejkolwiek zagranicznej kompaniï ${ }^{30}$.

Równolegle do przywoływanych informacji, dotyczacych problemów KAP i wymienionej kopalni boksytów, z którymi przed kilkoma laty związali się udziałowcy rosyjscy, w gazetach czarnogórskich pojawiały się w ostatnich latach również wiadomości o przygotowywanym nowym przetargu, dotyczacym budowy drugiego bloku elektrowni cieplnej w Pljevlji. Do udziału w nim, oprócz kompanii z Chin i środkowoeuropejskich państw-członków UE (Czech, Słowacji i Polski), sposobiła się również Rosyjska Państwowa Korporacja Energii Jądrowej (Rosatom) ${ }^{31}$.

Nadal zatem zauważalne pozostawało dążenie wielkiego biznesu z Rosji, powiązanego mniej lub bardziej czytelnie z Kremlem oraz z rosyjskim aparatem władzy wykonawczej, do zachowania wpływów na czarnogórski przemysł

inżynierowie $\mathrm{z}$ tego przedsiębiorstwa, zarzucaja manipulowanie ceną surowca i oszustwa w zakresie gwarantowania jego wydobycia, a nawet nieczyste zagrania lobbingowe czy wręcz łapówkarskie.

${ }^{29}$ Ibidem, zob. również: http://www.vijesti.me/vijesti/poljaci-i-madari-se-interesuju-za-boksite-796689 (dostęp 20 IX 2014); http://mondo.me/ a395064/Info/Drustvo/Poljaci-i-Madjari-zele-imovinu-Boksita.html (dostęp 20 IX 2014); http://crna.gora.me/vijesti/ekonomija/madari-da-kazu-kome-su-davali-procenat/ (dostęp 2 I 2015); Mađari ucenjuju tuđbom, „Dan”, 20 I 2015, s. 1; http://www.balkanmagazin.net/rudarstvo-i-metalurgija/ cid192-33596/neksan-novi-vlasnik-rudnika-boksita (dostęp 28 I 2015).

${ }^{30}$ Mađari ucenjuju..., s. 1.

${ }^{31}$ N. Uskoković, Kina protiv..., s. 2; Rusi opet... 
wydobywczy (w grę, mimo decyzji o ogłoszeniu stanu upadłości wyżej scharakteryzowanych przedsiębiorstw, wchodzi jeszcze kwestia przyszłości kopalni węgla kamiennego w Pljevlji ${ }^{32}$ ), jak również do uzyskania owych wpływów w sektorze energetycznym najmniejszego z postjugosłowiańskich państw (Termoelektrana).

W związku z obcą kontrolą nad czarnogórska gospodarką (z udziałem w tym Rosjan), niektórzy eksperci ze Stanów Zjednoczonych (Amerykanie Stephen R. Bowers i Marion T. Doss Junior oraz Mołdawianin Octavian Sofransky) wyrażali obawy odnośnie do mogacej postępować wasalizacji

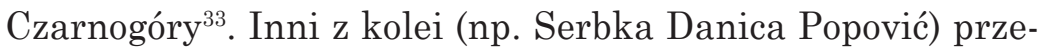
strzegali przed jej przekształceniem się w drugą Abchazję czy Osetię Południową (w nomenklaturze gruzińskiej określaną obecnie mianem „Region Cchinwali”), w których problemy gospodarcze krzyżują się ze społecznymi i politycznymi ${ }^{34}$. Obecne załamanie się niektórych, najbardziej przykuwających uwagę, rosyjskich biznesów w Czarnogórze nie oznacza wszak, że państwo to przestanie być przez Moskwę traktowane jako szczególnie pożądany obiekt gospodarczej, jak również wywiadowczej, penetracji.

Rosjanie wykazują w Podgoricy także aktywność w zabieganiu o przychylność dla swoich projektów energetycznych, na czele z South Stream - gazociagiem Gazpromu. Funkcjonowanie tegoż (o ile dojdzie do jego uruchomienia ${ }^{35}$ ) rosyjski rząd zamierza „ochraniać” przede wszystkim poprzez

${ }^{32}$ N. Uskoković, Kina protiv..., s. 2.

${ }^{33}$ O. Sofransky, S.R. Bowers, M.T. Doss Jr., op. cit.

${ }^{34}$ D. Bilefsky, A Russian Window on the West Montenegro Earns a new Nick-Name Moscow-on the Sea, "International Herald Tribune” (New York), 1 XI 2008.

${ }^{35}$ A. Kublik, Antyukraińska rura Gazpromu zatrzymana, „Gazeta Wyborcza", 6 XII 2013, s. 21. 
właściwe ukierunkowanie i intensyfikację pracy rozpoznawczo-informacyjnej rezydentur wywiadowczych Służby Wywiadu Zagranicznego (Stużba wnieszniej razwiedki, SWR) i Głównego Zarządu Wywiadowczego (Gtawnoje razwiedywatielnoje uprawlenije, GRU), ulokowanych $\mathrm{w}$ przedstawicielstwach dyplomatycznych, działających w państwach, które podpisały porozumienia o budowie tego gazociagu ${ }^{36}$. Niemniej, niemalże na pewno stwierdzić można, iż w powyższym celu zaplanowano już także wykorzystywanie rosyjskich siatek wywiadowczych, aktywnych w ambasadach i konsulatach w krajach sąsiednich, czyli m.in. w Czarnogórze. Wielce prawdopodobne jest zaangażowanie do tego struktur wywiadów cywilnego i wojskowego, które mogą zostać związane z tworzonym w południowoserbskim Nišu, być może nawet głównie jako „przykrywka” dla działań o charakterze niejawnym, Rosyjsko-Serbskim Centrum Humanitarnym. Jego gestorami sa Ministerstwo ds. Sytuacji Nadzwyczajnych Federacji Rosyjskiej oraz Ministerstwo Spraw Wewnętrznych Serbii. Pierwotnie określane było jako Centrum ds. Zadań Nadzwyczajnych ${ }^{37}$.

${ }^{36}$ Grono to tworzą państwa należące do UE: Austria, Bułgaria, Chorwacja, Grecja, Słowenia i Węgry oraz, ubiegająca się o członkostwo w niej, Serbia, należąca do Europejskiej Wspólnoty Energetycznej, w której kwestie rynku gazowego regulowane sa w oparciu o przepisy unijne. Na temat porozumienia rosyjsko-serbskiego w sprawie gazociagu zob. M. Stojanović, Premijer Srbije sa predsednikom Rusije juče u Moskvi: Vučić i Putin postigli dogovor o Južnom toku, http://www.danas.rs/danasrs/politika/vucic_i_putin_postigli_dogovor_o_ juznom_toku.56.html?news_id=285064 (dostęp 9 VII 2014).

${ }^{37}$ M. Korzeniewska-Wiszniewska, op. cit., s. 375-376. Należy zwrócić uwage na położenie miasta Niš. South Stream przebiegać miał właśnie nieopodal tego największego ośrodka miejskiego południowej Serbii; z niego zaś blisko jest już nie tylko do niestabilnych Doliny Preševskiej, Kosowa czy północnej Macedonii, ale także do Czarnogóry i Albanii (należącej do NATO). Ponadto, co przypomniane zostało we wskazanym artykule 
Podmioty rosyjskie w zauważalny sposób prowadzą na terytorium Czarnogóry także ekspansję w budownictwie. Wizytówką są tu nadmorskie hotele, wznoszone np. przez firmę Mirax Wiaczesława Lejbmanna i Siergieja Polonskiego (rosyjskie „fortece” na Riwierze Budvańskiej, gdzie pojawiaja się kluczowi moskiewscy biznesmeni i przedstawiciele Gazpromu, Łukoilu lub też, wspominanego już wyżej, VTB, wcześniej znanego jako Vniesztorgbank) ${ }^{38}$ oraz gwiazdy rozrywki (np. Madonna) ${ }^{39}$. Wykup ziemi i domów przez Rosjan na czarnogórskim wybrzeżu osiagnął już w latach 2005-2008 wyjątkowy rozmach (zainwestowało weń wówczas przeszło 30 tys. Rosjan ${ }^{40}$. Rosyjska obecność w Czarnogórze przyjęła zatem bardzo wymierny i wręcz spektakularny charakter. Demonstruja ją ponadto bezpośrednie połaczenia lotnicze z Moskwy (w sezonie letnim także z innych rosyjskich miast oraz, do niedawna, z wschodnioukraińskiego Doniecka) z Podgorica i nadmorskim miastem Tivat, jak również

Mirelli Korzeniewskiej-Wiszniewskiej, przekazom na temat rosyjsko-serbskiego projektu związanego z Nišem, podawanym w polskich mediach jesienią 2011 r., towarzyszyły informacje o podejrzeniach, iż inwestycja ta służyć będzie ulokowaniu w dogodnym miejscu rosyjskiej komórki. Miałaby ona prowadzić działania wywiadowcze ukierunkowane na elementy amerykańskiej tarczy antyrakietowej, które planuje się rozmieścić na terytorium sasiadującej z Serbią Rumunii, ibidem, s. 375, przypis 33.

${ }^{38}$ VTB na początku grudnia 2013 r. uznawany był za drugi największy bank Rosji (po Sbierbanku), I. Trusewicz, Rosyjskie banki państwowe sq dobrej myśli, „Rzeczpospolita”, 6 XII 2013, s. A10. Zob. również poświęcony problemowi wyprowadzania z Rosji przez tamtejsze banki (w tym VTB), w nie zawsze przejrzystych celach, potężnych sum (miliardy dolarów amerykańskich), „wpompowanych” w nie przez państwo rosyjskie w celu kredytowania zagrożonych rosyjskich przedsiębiorstw, W. Radziwinowicz, W Rosji kryzys to biznes, „Gazeta Wyborcza”, 12 XI 2013, s. 28.

${ }^{39}$ D. Bilefsky, op. cit.; zob. także „The Times” (London), 8 X 2008.

${ }^{40}$ D. Noack, op. cit. 
ekspansja rosyjskich, zwolnionych z obowiązku wizowego, turystów $^{41}$. Odnotować należy też przypadki zyskiwania obywatelstwa Czarnogóry przez cudzoziemców (w tym Rosjan) po zainwestowaniu w niej powyżej $0,5 \mathrm{mln}$ euro $^{42}$ (a więc już

${ }^{41}$ Rosja i Czarnogóra wzajemnie znosza wizy, „BEST OSW - Bałkany i Europa Środkowa. Tygodnik OSW”, 1 X 2008, nr 31 (65), s. 4.

${ }^{42}$ Czarnogórska ustawa o obywatelstwie umożliwiała jeszcze parę lat temu nadanie go z takiego tytułu. W oparciu o $§ 12$ tejże ustawy możliwe jest przyznanie obywatelstwa cudzoziemcowi ze względu na ważny ekonomiczny i/lub polityczny interes Czarnogóry. Regulacje prawne, oficjalnie umożliwiające przyznanie obywatelstwa $\mathrm{w}$ zamian za inwestycje lub po prostu określonej wysokości wpłatę do budżetu państwa, funkcjonuja również w innych krajach (Malta, Cypr, Bułgaria, Dominikana, Saint Kitts i Nevis, Antigua i Barbuda, a z pewnymi obostrzeniami także Austria), J. Przybylski, Rzqd sprzeda nawet paszport, „Tygodnik Lisickiego Do Rzeczy", 25 XI-1 XII 2013, s. 80-81. Z czarnogórskiego przepisu skorzystano, nadajacc w 2010 r. obywatelstwo Thaksinowi Shinawatrze, zbiegłemu z Królestwa Tajlandii miliarderowi i byłemu premierowi (2001-2006) tego państwa, http://www.economynews.us/economy/thaksin-shinawatra-leverages-montenegrin-citizenship/ (dostęp 5 XII 2013); http://www.reuters.com/ article/idUSTRE62G2QM20100317 (dostęp 5 XII 2013). W świetle sprawy T. Shinawatry (w mniejszym stopniu również na przykładzie wcześniejszego zamieszania z prawdopodobnym ukrywaniem się w Czarnogórze amerykańskiego szachisty B. Fischera), opozycja antyđukanoviciowska przedstawia niekiedy własne państwo jako potencjalną przystań podejrzanych osób, zbiegów i kryminalistów. W mediach pojawiają się informacje identyfikujące jako główne miejsce pobytu T. Shinawatry Dubaj w Zjednoczonych Emiratach Arabskich. To właśnie stamtąd miał on przybyć do Czarnogóry, zatrzymując się w marcu 2010 r. w mieście Miločer koło Budvy, Roćen brani Tajland od Šinavatre, http://www.rts.rs/page/stories/sr/story/11/ Region/571861/Ro\%C4\%87en+brani+Tajland+od+\%C5\%A0inavatre.html (dostęp 7 XII 2013); zob. też: J. Giziński, Polityczny cyklon w Bangkoku, „Rzeczpospolita”, 28 XI 2013, s. A9; M. Kruczkowska, Gorqczka w Bangkoku, „Gazeta Wyborcza”, 30 XI-1 XII 2013, s. 13. Frapujące jest również zainteresowanie prezesującej Radzie Ministrów Tajlandii - Yingluck Shinawatry (rodzonej siostry T. Shinawatry) - kooperacją z Czarnogórą i odwiedzanie przez nią tego państwa, zob. D. Murić, Prva sestra Tajlanda: Jingluk 
nie tylko, jak było to jeszcze kilka lat temu, skromne symbole, w postaci „ławeczki Puszkina” - dar merostwa Moskwy dla Podgoricy).

W ocenie Dragana Teleskovicia (według informacji medialnych - byłego funkcjonariusza jugosłowiańskiego kontrwywiadu cywilnego), Czarnogóra stanowi jedną $\mathrm{z}$ istotniejszych bałkańskich baz dla penetracji prowadzonej przez służby specjalne Federacji Rosyjskiej, państw Zachodu (szczególnie: Wielkiej Brytanii, USA, RFN, Austrii i Włoch), sąsiadów z byłej Jugosławii (w tym - dodać należy - Serbii, czego wymieniony autor z oczywistych względów nie akcentuje) oraz krajów arabskich ${ }^{43}$.

Obok wciąż ważnych kwestii terroryzmu, obrotu bronia i narkotykami czy stabilności Kosowa i zislamizowanego regionu Sandżaku Nowopazarskiego, szczególne znaczenie dla penetrujacych Czarnogórę (i szerzej - Bałkany) służb specjalnych, uzyskały dziśs zagadnienia gospodarcze.

Rosyjski wywiad ekonomiczny, prowadzony w Czarnogórze głównie przez SWR, napotyka wprawdzie konkurencję ze strony brytyjskiej służby Secret Intelligence Service (SIS, MI6), niemieckiej Bundesnachrichtendienst (BND) czy włoskiej Agenzia Informazioni e Sicurezza Esterna (AISA). Sądzi się jednak, iż jest on w swoich przedsięwzięciach i dyskontowaniu pracy agentury bardzo skuteczny. Dociera do urzędników, biznesmenów oraz polityków. Przygotowuje grunt pod kluczowe inwestycje (lobbing) i osłania je. Lokuje ludzi w strukturach firm (własnych, mieszanych kapitałowo

Šinavatra stiže u Crnu Goru, „Vijesti”, 9 IX 2013, s. 1. Ciekawe są także informacje o tym, jakoby T. Shinawatra alias Thaki Shinegra oprócz czarnogórskiego posiadał jeszcze paszporty nikaraguański i ugandyjski, zob. cyt. wyżej tekst: Roćen brani Tajland...

${ }^{43}$ Č. Mranović, Špijuni su na vašem platnom spisku, „Revija Dana” (Podgorica), 4 II 2009. 
i jednorodnie czarnogórskich) $)^{44}$. Idąc dalej, hipotetycznie założyć można i to, iż, budując w państwie gospodarczo słabym ${ }^{45}$, wciąż jeszcze skorumpowanym ${ }^{46}$, niedomagającym administracyjnie i nie posiadającym ugruntowanej demokracji, swoiste, nieformalne enklawy rosyjskie - wywiad cywilny SWR (podobnie wojskowe GRU, interesujące się niestabilnym sąsiednim Kosowem i państwami regionu należącymi już, bądź też, jak Czarnogóra, pretendującymi do $\mathrm{NATO}^{47}$ ) wykorzystywać może czarnogórskie przyczółki jako znakomite miejsce

${ }^{44}$ Ibidem.

${ }^{45}$ Opinie o narastającym kryzysie gospodarczym Czarnogóry zob. Ma. M., Vode države u stečaj, „Vijesti”, 7 IX 2013, s. 5.

${ }^{46}$ Przeciwdziałanie korupcji w Czarnogórze z pewnością nie jest, z punktu widzenia standardów zachodnich, satysfakcjonujące. Raczej trudno też wyobrazić sobie naprawdę efektywne zwalczanie jej przez tamtejsze służby specjalne, co, jak zdaje się sugerować polski prawnik i publicysta, mający czarnogórskie korzenie, może mieć pewne podłoże społeczno-zwyczajowe: $W$ matej społeczności klanowej rodzina wzajemnie sie popiera. $Z$ tych względów w Czarnogórze raczej nie mogtoby powstać CBA, bo konflikt między rodzinami o to, kto będzie kontrolować tę stużbę, mógtby wywołać kolejnq wojnę domowq na Batkanach, L.A. Szaranowicz, Ima veze, „Wręcz Przeciwnie", 2 X 2011, s. 31.

${ }^{47}$ Niewykluczone jest także zainteresowanie Federacji Rosyjskiej wybrzeżem czarnogórskim jako bazą prowadzenia operacji, operującej też na Morzu Śródziemnym, jej marynarki wojennej. Wywiadowcze rozpoznanie tego rodzaju możliwości może stanowić zadanie GRU. Poszlaki, wskazujące na sondowanie pewnych możliwości we wskazanej materii, pojawiły się na początku września 2013 r., w kontekście napięcia międzynarodowego spowodowanego przez sytuację w Syrii, zob. V.K., MO: ruski ratni brodovi ne dolaze, „Dnevne novine”, 6 IX 2013, s. 5. Wartościowym opracowaniem, poświęconym GRU, pomagającym zrozumieć specyfikę tej służby specjalnej i działań także obecnie przez nią prowadzonych, pozostaje książka Wiktora Suworowa (Władimira Rezuna), napisana jeszcze w okresie zimnowojennym, a więc z myślą o radzieckim, a nie rosyjskim, wywiadzie wojskowym, noszącym tę samą nazwę, zob. W. Suworow, GRU. Radziecki wywiad wojskowy, Poznań 2010. 
ukrywania czy przerzucania w inne miejsca swoich wywiadowców oraz tzw. prania pieniędzy, przeznaczanych m.in. na pozaprawne działania służb (drugi Cypr?) ${ }^{48}$. Niektórzy obserwatorzy sytuacji państw bałkańskich gotowi sa podzielić pogląd znanego pakistańsko-brytyjskiego intelektualisty Tariqa Aliego, że Czarnogóra jest państwem, które na pewno nie przetrwałoby bez pieniędzy rosyjskiej mafii [...], i które UE chce objać integracja, bojac się Rosjan ${ }^{49}$. Słowa te, interpretowane $\mathrm{w}$ powiązaniu z wyżej zasygnalizowanymi możliwościami rosyjskimi, nabierają nowego, interesującego wydźwięku. Kwestię zauważalnej rosyjskiej przychylności dla czarnogórskich aspiracji do członkostwa w UE (popartych oficjalnie w listopadzie 2010 r. przez Komisję Europejska ${ }^{50}$ ) warto przeanalizować w tym świetle.

Poważniejsze kontrowersje wywoływać może stosunek Kremla do czarnogórskich starań o członkostwo w NATO. Pokusa posiadania swojego „konia trojańskiego” w Sojuszu ma dla oficjalnej Moskwy niebagatelne znaczenie. Federacja Rosyjska zacieśnia jednak w ostatnich latach swoje relacje z Serbia, sąsiadująca z Czarnogóra, dążąc raczej do odepchnięcia od niej i jej bezpośredniego otoczenia struktur

${ }^{48}$ Proceder tzw. prania w Czarnogórze pieniędzy wytransferowanych z Rosji (choć nie ma w tekście o tym przypadku sugestii jego autora - dziennikarza „Vijesti” odnośnie do roli służb specjalnych) potwierdza i dobrze ilustruje artykuł, dotyczący interesów realizowanych w mieście Bar przez niejakiego Vladimira V. Abakumova (zakup nieruchomości). Na jego konto przelewała pieniądze zbiegła z Rosji była funkcjonariuszka fiskusa z Moskwy - Olga Stepanova, oskarżona o kradzież około 230 mln euro, M.R., Ukradenim novcem kupovala nekretine u Crnoj Gori i Dubaju, „Vijesti”, 8 IX 2013, s. 5.

${ }^{49}$ T. Ali, Evropa je mrtav kontynent, ,Politika” (Beograd), 10 XI 2013 (w rubryce pt. Razgovor nedelje).

${ }^{50}$ H. Ćurić, Podgorica slavi približavanje EU, „Politika”, 11 XI 2010, s. 4; „Danas” (Beograd), 10 XI 2010, s. 13; „Pobjeda”, 2 XII 2010. 
NATO. Wejście Czarnogóry do Paktu Północnoatlantyckiego, który uznaje Rosję jako przeciwnika (co jest przede wszystkim odpowiedzią na agresywne kroki rosyjskie w stosunku do Ukrainy i prowokacje wymierzane przez Federację Rosyjską w członków NATO), traktowane jest aktualnie w Moskwie jako scenariusz niekorzystny. Niewykluczone, iż zapobieżeniu mu, bądź choćby odsunięciu w czasie jego realizacji, służyć będzie stosowanie przez Rosjan polityki okresowego wyhamowywania, a nawet zamrażania, inwestycji lokowanych w małym nadadriatyckim państwie. Może to generować w nim określone perturbacje budżetowe, czy wręcz ekonomiczno-polityczną destabilizację. Właśnie w takim kontekście na zagrożenia, związane z możliwością redukcji inwestycji rosyjskich w Czarnogórze, zwrócił uwagę minister spraw zagranicznych Czarnogóry, Igor Lukšić, w rozmowie z szefem dyplomacji niemieckiej - Frankiem-Walterem Steinmaierem, w kwietniu 2015 r. ${ }^{51}$

Zamykając niniejsze rozważania, należy zauważyć, iż istotne dla szacowania możliwości prowadzenia działań przez służby specjalne Federacji Rosyjskiej w Czarnogórze jest też to, jakiego przeciwnika posiadają one $\mathrm{w}$ tym państwie. Jest nim, kierowana od sierpnia 2010 r. do marca 2012 r. przez Vladana Jokicia ${ }^{52}$, a następnie przez Borę Vučinicia, Agencja Bezpieczeństwa Narodowego (Agencija za nacionalnu bezbjednost, ANB) - spadkobierczyni byłej Służby Bezpieczeństwa Państwowego (Služba državne

${ }^{51}$ „Rosja destabilizuje Czarnogórę”. Kreml dla własnych interesów gotowy jest rozpętać nowe piekło na Bałkanach?, http://wpolityce.pl/swiat/ 242228-rosja-destabilizuje-czarnogore-kreml-dla-wlasnych-interesow-gotowy-jest-rozpetac-nowe-pieklo-na-balkanach (dostęp 27 IV 2015).

${ }^{52}$ Vladan Jokić novi direktor Agencije za bezbednost Crne Gore, http:// www.rtv.rs (dostęp 29 VII 2010); http://www.anb.me/CV\%Direktor.html (dostęp 12 XII 2010). 
bezbednosti, SDB) $)^{53}$, której szefowali Vukašin Maraš i Dušan Marković (okresowo minister bez teki - doradca premiera ds. relacji z NATO i UE) ${ }^{54}$. ANB, scalony kontrwywiad i wywiad, stanowi z pewnością strukturę znajdująca się jeszcze in statu nascendi, choć jej właściwości, ujęte ustawowo, są dość szerokie ${ }^{55}$. Problematyczną kwestią pozostaje jednak to, jak względem Rosjan i ich ekspansji (gospodarczej, politycznej i wywiadowczej) w Czarnogórze nastawieni sa polityczni włodarze tego państwa i mocodawcy ANB, dryfujący ku sympatiom prorosyjskim.

Zakładany w opracowaniach eksperckich oraz w tekstach publicystycznych związek pewnych rosyjskich działań ekonomicznych (np. inwestycji w wydobycie surowców, przesył nośników energii itp.), prowadzonych poza granicami Federacji Rosyjskiej przez ludzi Moskwy, z uzyskująca coraz większy rozmach aktywnością rosyjskich służb specjalnych na obszarze krajów, w których inwestuja podmioty gospodarcze

${ }^{53}$ Informacje na: http://www.anb.me (dostęp 12 XII 2010).

${ }^{54} \mathrm{~J}$. Targalski, Mechanizmy demontażu komunizmu $w$ Jugostawii na przyktadzie Stowenii i Serbii (1986-1991), praca doktorska, napisana pod kier. prof. dr. P. Wieczorkiewicza, Wyższa Szkoła Humanistyczna im. Aleksandra Gieysztora w Pułtusku, 2006, s. 235-238; S. R., SDB Crne Gore - SDB Srbije, http://www.aimpress.ch/dyn/pubs/archive/data/199510/51013002 (dostęp 12 XII 2010); http://www.yurope.com/nasa-borba/arhiva/ Maj97/0405/0405_15.HTM (dostęp 2 XII 2010); http://forum.cafemontenegro.com/showthread.php?t=3873 (dostęp 13 XII 2010); Šef tajne policije Crne Gore postauljen za ministra, http://www.rtv.rs (dostęp 30 VII 2010); http://seebiz.eu/cg/politika/nebojsa-medojevic-dusko-markovic-nasljeduje-mila (dostęp 10 XII 2010); http://www.vesti.rs/Region/Preminuo-Vukasin-Maras.html (dostęp 12 XII 2010); Đukanović ide u NATO, premier Duško Marković?, „Kurir” (Beograd), 7 VII 2010.

${ }^{55}$ Tekst ustawy o ANB: „Služebni list Crne Gore” (Podgorica), $5 \mathrm{~V}$ 2008, br. 28/05; http://www.amb.me (dostęp 13 XII 2010); http://www.ccmr-bg.org (dostęp 13 XII 2010). 
kontrolowane przez powiązanych z Kremlem oligarchów ${ }^{56}$, pozwala stawiać hipotezy, dotyczące wysokiego poziomu infiltracji wywiadowczej takich państw przez Rosjan.

W odniesieniu do przypadku czarnogórskiego, dodatkowo podkreślić należy, iż faktyczne możliwości przeciwdziałania przez Podgorice wpływom rosyjskich służb specjalnych są niewielkie. Decyduje o tym rażąca dysproporcja potencjałów służb rosyjskich i czarnogórskiej ANB oraz przyjmowanie przez władze Czarnogóry orientacji prorosyjskiej.

Co do charakteru infiltracji Czarnogóry przez stronę rosyjska, której prowadzenie zakłada się w niniejszych

${ }^{56}$ Zob. m.in.: P. Earley, Towarzysz J. Tajemnice szefa rosyjskiej siatki szpiegowskiej $w$ Stanach Zjednoczonych po zimnej wojnie, przeł. M. Szymański, Poznań 2008; E. Lucas, Nowa zimna wojna. Jak Kreml zagraża Zachodowi, przeł. J. Stawski, Poznań 2008; idem, Deception: The Untold Story of East-West Espionage Today, London 2012; A. Kowalski, Rosyjski sztylet. Działalność wywiadu nielegalnego, Łomianki 2013; idem, Odbudowa imperium, „Gazeta Polska”, 27 XI 2013; R. Stanić, Špijunski rat u Srbiji, „Evropa. Srpski nacjonalni nedeljnik” (Beograd), 10 III 2005, s. 26-31; S. Čngradin, Crveni orkestar u Ruskom domu. „Danas” serijal: ako je Srbija, kako kažu ,patriotski” krugovi, puna zapadnih špijuna - ko „,radi za Ruse”?, „Danas”, 30 IX 2011, s. 1-2; J. Diković, Kako je „Danas” pravi ruski vikiliks: ko u Srbiji radi za Ruse, ,Novi standard” (Beograd), 3 X 2011, http://www.standard.rs/kako-danas-pravi-ruski-vikiliks-ko-u-srbiji-radi-za-ruse-2.html (dostęp 7 XII 2013); K. Trębski, P. Wipler (przy współpracy: D. Ćosić, R. Przedmojskiego i S. Stodolaka), Kiedy zabraknie nam gazu, „Wprost”, 18 I 2009, s. 6-11; L.M. Bednarz, J. Kowalski, Rosja bez gazu, „Wprost”, 18 I 2009, s. 12-13; W. Lorenz, Kreml stawia na szpiegów, „Rzeczpospolita”, 7-9 IV 2012, s. A8; Racja stanu, racja klanu, rozmowa Adama Tycnera z Włodzimierzem Marciniakiem, „Rzeczpospolita” (dodatek „PlusMinus”), 27-28 X 2012, s. P2-P3; I. Janke, Bidzina - rosyjski projekt, „Rzeczpospolita” (dodatek „PlusMinus”), 27-28 X 2012, s. P5; A. Łomanowski, Imperium kontratakuje, „Rzeczpospolita”, 7-8 XII 2013, s. A1; idem, Miłość płatna i darmowa, „Rzeczpospolita” (dodatek „PlusMinus"), 7-8 XII 2013, s. P2-P3. 
rozważaniach, podkreślić należy, iż jest ona najprawdopodobniej głównie infiltracją „miękką” (co nie oznacza: słabsza, mniej intensywna), dokonywaną w większym stopniu przez przedstawicieli służb będących tzw. głęboko zakonspirowanymi oficerami (GZO), czy nawet nielegałami ${ }^{57}$, uplasowanymi poza struktura placówki dyplomatycznej (w firmach i instytucjach rosyjskich). Wywiadowcy tego rodzaju z reguły nie sporządzaja standardowych, przekazywanych w rutynowy sposób, raportów dla misji swojego państwa. Jako tacy stanowią grupę trudniejszą do zidentyfikowania przez miejscowy kontrwywiad. Działając na polu pozyskiwania kontaktów osobowych i informacji, sa mniej agresywni (mniej klasycznych werbunków, więcej wypracowywania tzw. kontaktów informacyjnych w gremiach złożonych z dysponentów cennych informacji, dzielacych się nimi bez świadomości rzeczywistej roli uzyskujących ją osób, ani nawet ich faktycznego pochodzenia czy narodowości), lecz za to bardziej inwazyjni i nierzadko skuteczniejsi.

${ }^{57}$ Pojęcie nielegat na gruncie powstałej w Polsce literatury przedmiotu przybliża i objaśnia się najszerzej we wskazanej wyżej publikacji: A. Kowalski, Rosyjski sztylet... 